\title{
PENGARUH FEMALE CEO TERHADAP KUALITAS LAPORAN KEUANGAN: PREFERENSI RISIKO SEBAGAI PEMODERASI
}

\author{
NUR JAMALIYAH ISRAINI \\ Universitas Airlangga, Jl. Airlangga No.4, Airlangga, Kec. Gubeng, Surabaya, Indonesia \\ nurjamaliyah.israini@gmail.com
}

\begin{abstract}
The aim of this research is to examine the impact of female CEO on financial reporting quality. This reasearch also adds risk preferences to moderate the relations of female CEO and financial reporting quality. Female CEO is measured by CEO gender dummy. Absolute discretionary accrual is the proxy of financial reporting quality. Audit opinions are also added as alternative measurement of financial reporting quality. This reasearch used 1653 non financial-companies listed in Indonesia Stock Exchange period 2014-2018, selected based on several criteria. Based on the result, female CEO has a negative effect on absolute discretionary accruals which indicate that it can improve the financial reporting quality. However, the effect didn't show the significant effect. Female CEO have positive significant on unqualified audit opinion that indicate higher quality of financial reporting. Risk preference can moderate the relationship of female CEO and financial reporting quality. Female CEO who have risk taking preference tend to do earnings management which can reduce the quality of financial reporting.
\end{abstract}

Keywords: Female CEO, absolute discretionary accrualm audit opinions, risk preference.

Abstrak: Penelitian ini bertujuan untuk menguji pengaruh female CEO terhadap kualitas laporan keuangan. Penelitian ini juga menambahkan preferensi risiko untuk memoderasi hubungan female CEO dan kualitas laporan keuangan. Female CEO diukur dengan dummy gender CEO. Absolut akrual diskresioner digunakan sebagai proksi kualitas laporan keuangan. Opini audit juga ditambahkan sebagai pengukuran alternatif kualitas laporan keuangan. Sampel penelitian ini adalah 1653 perusahaan non keuangan yang terdaftar di Bursa Efek Indonesia tahun 2014-2018, yang dipilih berdasarkan beberapa kriteria. Berdasarkan hasil pengujian, female CEO berpengaruh negatif terhadap absolut akrual diskresioner yang menunjukkan bahwa dapat meningkatkan kualitas laporan keuangan. Namun, pengaruh tersebut tidak menunjukkan hasil signifikan. Female CEO berpengaruh positif signifikan terhadap opini audit WTP yang mengindikasikan laporan keuangan lebih berkualitas. Preferensi risiko dapat memoderasi hubungan female CEO dan kualitas laporan keuangan. Female CEO yang memiliki preferensi risk taking cenderung melakukan earnings management yang dapat menurunkan kualitas laporan keuangan.

Kata kunci: Female CEO, absolut akrual diskresioner, opini audit, preferensi risiko

\section{PENDAHULUAN}

Salah satu isu tata kelola perusahaan yang baik adalah dengan adanya keberagaman dalam komposisi dewan direksi. Keragaman dapat meningkatkan kreativitas, inovasi, serta pemecahan masalah yang lebih efektif 
(Carter et al, 2003). Keragaman pada dewan direksi diharapkan mampu meningkatkan transparansi informasi dan kinerja perusahaan untuk mendapatkan kepercayaan para pemegang saham sehingga menciptakan tata kelola perusahaan yang baik. Keberagaman dewan direksi salah satunya dapat dilihat dari keragaman gender.

Pada saat ini, banyak wanita yang menduduki posisi manajemen dalam berbagai perusahaan. Wanita memiliki keahlian dan kemampuan sebagai seorang profesional di bidangnya, seperti yang terdapat dalam Forbes Asia's Power Businesswomen (2019), 3 diantaranya adalah pengusaha wanita sukses dari Indonesia. Hasil survey global yang dilakukan oleh Grant Thornton International menunjukkan bahwa persentasi bisnis dengan setidaknya satu wanita dalam senior management meningkat menjadi $87 \%$ pada tahun 2019. Di wilayah ASEAN (termasuk Indonesia), proporsi bisnis yang memiliki wanita dalam senior management sebesar $94 \%$ dengan proporsi wanita sebesar $28 \%$. $\mathrm{Hal}$ ini lebih tinggi dibandingkan wilayah Amerika Utara yang hanya $92 \%$ atau Uni Eropa sebesar $84 \%$ untuk jumlah wanita di posisi senior management. Hal ini menunjukkan bahwa eksistensi wanita dalam manajemen semakin meningkat dan membuktikan bahwa wanita khususnya di Indonesia mampu memimpin dan mengelola perusahaan dengan baik.

Keragaman gender dalam dewan direksi diduga mampu meningkatkan kualitas pelaporan keuangan karena berbagai alasan. Pertama, keragaman gender dapat menyebabkan wawasan dewan direksi menjadi lebih luas (Carter et al. 2003, Smith et al. 2005, Adams \& Ferreira 2009) sehingga terdapat berbagai pertimbangan dalam menyajikan informasi laporan keuangan agar lebih berkualitas.
Keragaman dapat meningkatkan profitabilitas dan nilai perusahaan dengan menambahkan karakteristik unik, kemampuan dan bakat dalam dewan (Kilic \& Kuzey 2016). Keragaman gender dapat menyebabkan kualitas dalam memecahkan masalah menjadi lebih baik sehingga terdapat pendapat yang lebih beragam untuk dijadikan pertimbangan dan meningkatkan proses pengambilan keputusan. Selain itu, keragaman mungkin dapat meningkatkan tranparansi di tingkat direksi (Panzer \& Muller 2015)

Kedua, wanita memiliki team work yang lebih baik dibandingkan dengan pria. Wanita juga memiliki gaya komunikasi yang lebih partisipatif sehingga sistem pengambilan keputusan akan lebih objektif. Wanita cenderung untuk membantu orang lain dan bekerja sama sementara pria fokus untuk memaksimalkan keuntungan dan meningkatkan tangga karir sehingga cenderung melakukan earnings management yang dapat menurunkan kualitas laporan keuangan (Harakeh et al. 2019).

Ketiga, wanita cenderung lebih beretika dibandingkan dengan pria. Selain itu wanita juga lebih sensitif terhadap masalah sosial (Al-Shaer \& Zaman 2016). Wanita lebih mendukung proyek dengan tanggung jawab sosial yang lebih tinggi. Pada penelitian sebelumnya, wanita lebih kecil kemungkinan terlibat dalam kecurangan pelaporan keuangan dibandingkan dengan pria (Khishnan \& Parsons, 2008, Harakeh et al. 2019). Wanita memiliki kemungkinan lebih kecil untuk mendapatkan keuntungan finansial yang tidak bermoral karena lebih menolak risiko yang lebih tinggi (Harakeh et al. 2019). Wanita juga cenderung mengambil hubungan yang dapat membangun kepercayaan (Al-Shaer \& Zaman 2016), sehingga laporan keuangan akan lebih 
berkualitas untuk mendapatkan kepercayaan dari pemangku kepentingan.

Di sisi lain, beberapa penelitian menyebutkan bahwa keragaman gender tidak memiliki hubungan yang signifikan terhadap kualitas pelaporan keuangan. Kyaw et al. (2015) mengungkapkan bahwa wanita tidak akan memiliki manfaat bagi perusahaan jika lingkungan perusahaan tersebut tidak memperdayakan mereka. Rose (2007) dan Carter (2010) juga menunjukkan hasil serupa yaitu keragaman gender tidak memiliki pengaruh terhadap kinerja perusahaan. Hal ini didasari oleh terlalu sedikitnya wanita yang tergabung dalam dewan direksi.

Karena ketidakkonsistenan hasil penelitian hubungan antara keragaman gender dengan kualitas laporan keuangan, penelitian ini bertujuan untuk menguji kembali hubungan keragaman gender dan kualitas laporan keuangan. Berdasarkan upper echelon theory (Hambrick \& Mason 1984), karakteristik manajemen puncak, seperti usia, pendidikan, gaya kepemimpinan, pengalaman fungsional dan gender, suatu perusahaan mempengaruhi pemilihan strategi dalam pengambilan keputusan termasuk tingkat kualitas laporan keuangan yang disajikan perusahaan.

Penelitian ini menduga bahwa ketidakkonsistenan hasil penelitian sebelumnya tentang hubungan antara keragaman gender dengan kualitas laporan keuangan dipengaruhi oleh preferensi risiko tokoh wanita yang berperan dalam dewan direksi/komisaris. Terdapat anggapan bahwa wanita lebih menghindari risiko (risk adverse) dan pria lebih menyukai tantangan dengan mengambil risiko (risk taking). Perusahaan yang memiliki proporsi direktur wanita lebih tinggi, cenderung kurang dalam mengambil risiko (Peni \& Vahamaa 2010; Sila et al. 2016). Hasil studi empiris Hoang et al. (2019) menunjukkan bahwa perusahaan dengan CEO wanita memiliki indeks risiko lebih rendah daripada perusahaan dengan CEO pria. Wanita juga dapat lebih dipercaya dibandingkan dengan pria dan kecil kemungkinan melakukan manipulasi terhadap laporan keuangan menurut Peni dan Vahamaa (2010). Perbedaan gender tidak hanya sebatas jenis kelamin, melainkan juga sifat maskulin dan feminim (Taleb 2010). Perbedaan sifat ini mengarah pada perbedaan bertingkah laku termasuk dalam pengambilan keputusan. Wanita cenderung lebih mengedepankan naluri dan perasaan dan menghindari risiko (risk averse), sedangkan pria lebih mengedepankan logika, menyukai tantangan, dan mengambil risiko (risk taking).

Kendati secara rata-rata wanita lebih cenderung menghindari risiko, karakter secara individual manajemen wanita bisa jadi memiliki preferensi risiko berbeda. Pernyataan bahwa wanita lebih menghindari risiko bisa jadi hanya stereotype. Schubert et al. (1999) menunjukkan bahwa konteks keputusan berisiko yang dihadapi mempengaruhi tingkat penghindaran risiko baik laki-laki maupun wanita. Schubert et al (1999) bahkan tidak menemukan perbedaan antara laki-laki dan wanita saat subyek eksperimen dihadapkan pada keputusankeputusan berisiko yang kontekstual. Hallant \& Vaillant (2008) dan Jianakoplos dan Bernasek (1998) menunjukkan bahwa tingkat pengambilan risiko lintas gender dipengaruhi karakter individual subyek penelitian.

Penelitian ini menduga bahwa manajemen wanita yang cenderung risk taking akan menurunkan kualitas laporan keuangan karena beberapa alasan. Pertama, wanita yang risk taking akan mengambil keputusan bisnis yang lebih berisiko dan mempengaruhi volatilitas kinerja perusahaan sehingga daya prediksi laporan keuangan terhadap kinerja masa depan berkurang. Kedua, wanita yang risk 
taking memiliki keberanian lebih untuk melakukan manajemen laba agar kinerja perusahaan dilaporkan secara memuaskan untuk kepentingan manajemen maupun publik sehingga kualitas laporan keuangan berkurang.

Sampel yang digunakan dalam penelitian ini adalah perusahaan non keuangan yang terdaftar di Bursa Efek Indonesia periode 2014-2018. Female CEO diukur dengan dummy gender direktur utama. Pengukuran kualitas pelaporan keuangan menggunakan Discretionary Accruals-Modified Jones Model dan opini audit sebagai analisis tambahan. Analisis dan pengujian hipotesis menggunakan Random Effect Model-General Least Square (GLS) dan regresi probit untuk analisis tambahan dengan perangkat lunak STATA 14.

Hasil penelitian ini membuktikan bahwa female CEO dapat mengurangi akrual diskresioner namun tidak memiliki hubungan yang signifikan dengan kualitas pelaporan keuangan. Hasil penelitian ini sesuai dengan penelitian yang dilakukan oleh Kyaw et al (2015). Tidak adanya hubungan tersebut bisa jadi dikarenakan jumlah wanita yang menduduki posisi eksekutif sangat sedikit (Rose, 2007; Carter, 2010). Persentase Direktur Utama wanita hanya sebesar $6,83 \%$ dan hanya sebesar $41,15 \%$ perusahaan yang paling sedikitnya memiliki satu wanita dalam Dewan direksi. Dengan demikian, peran wanita dalam pengambilan keputusan perusahaan masih kurang dominan dibanding pria. Selain itu, penelitian ini menunjukkan bahwa direksi wanita yang memiliki preferensi risiko tinggi cenderung menyajikan laporan keuangan dengan diskresionari akrual lebih tinggi. Dengan demikian, preferensi risiko direksi wanita mempengaruhi hubungan antara gender direksi dan kualitas laporan keuangan. Penelitian ini juga membuktikan bahwa CEO wanita cenderung mendapat opini audit wajar tanpa pengecualian yang menunjukkan bahwa laporan keuangan lebih berkualitas. Hasil efek moderasi preferensi risiko terhadap opini audit tidak konsisten dengan hasil pada variabel absolut akrual diskresioner.

Penelitian ini memberikan kontribusi pada literatur dengan memberikan bukti yang menjelaskan upper echelon theory bahwa karakter pribadi manajemen yang bisa mempengaruhi keputusan perusahaan bisa jadi bergantung seberapa dominan individu tersebut dalam pengambilan keputusan perusahaan. Selain itu, bauran karakter berbeda di manajemen puncak bisa jadi mengurangi dominasi pengaruh salah satu karakter individu. Penelitian ini menemukan bahwa CEO wanita tidak memiliki hubungan signifikan terhadap kualitas pelaporan keuangan bisa jadi karena peran wanita dalam direksi terbaur dengan peran direksi lelaki yang jumlahnya masih mendominasi dewan direksi. Lebih lanjut, penelitian ini berkontribusi dengan menunjukkan bahwa preferensi risiko direksi wanita berpengaruh dalam keputusan penyajian laporan keuangan. Dengan demikian, preferensi risiko individu manajemen bisa jadi melampaui kelompok gender dalam menjelaskan variasi kualitas laporan keuangan perusahaan.

Penelitian ini disajikan dalam lima bagian (bab). Pada bab 2, mengulas tinjauan singkat tentang Agency Theory dan Upper Echelon Theory untuk mengembangkan hipotesis. Bab 3 menguraikan metode penelitian dalam hal sampel, data, pengukuran variabel dan model penelitian. Bab 4 melaporkan hasil empiris serta pembahasan mengenai hubungan female CEO terhadap kualitas pelaporan keuangan. Bab terakhir memberikan ringkasan dan menarik 
kesimpulan serta memberikan saran kepada pihak yang berkepentingan.

\section{Upper Echelon Theory}

Upper Echelon Theory (UET) merupakan teori yang dikembangkan oleh Hambrick \& Mason (1984) yang mengungkapkan bahwa karakteristik manajerial dapat digunakan untuk memprediksi outcome suatu organisasi. Outcome organisasi dan strategi organisasi dipengaruhi oleh nilai-nilai dan dasar kognitif dari pelaku yang kuat dalam organisasi, yaitu Direktur Utama (Manner 2010). Direktur Utama memiliki dampak secara langsung terhadap outcomes perusahaan karena memiliki tanggungjawab atas organisasi secara keseluruhan. Teori ini menunjukkan bahwa semakin kompleks suatu keputusan, maka semakin penting karakteristik para pembuat keputusan. Karakteristik tersebut seperti usia, pendidikan, pengalaman fungsional, dan gaya kepemimpinan. Prinsip UET mengakui bahwa karakteristik Manajemen Puncak yang berbeda dapat mempengaruhi keputusan pemilihan strategi perusahaan dan kinerja organisasi (Ting et al. 2015).

Dari perspektif UET, gender manajemen puncak bisa memengaruhi pilihan strategi dan outcome perusahaan. Kendati demikian, UET tidak menyarankan pengaruh spesifik gender manajemen puncak terhadap pengambilan keputusan perusahaan. Oleh sebab itu, penelitian ini menduga bahwa gender manajemen puncak akan mempengaruhi kualitas laporan keuangan tanpa menghipotesiskan arah hubungannya.

\section{Agency Theory}

Agency theory merupakan dasar yang digunakan untuk memahami tata kelola perusahaan. Teori keagenan ini menjelaskan kontrak antara pemegang saham selaku prinsipal dengan manajemen sebagai agen. Hubungan keagenan menggambarkan prinsipal melibatkan agen untuk melakukan beberapa pekerjaan atas nama mereka dan mendelegasikan wewenang pengambilan keputusan kepada agen (Jensen \& Meckling, 1976).

Teori ini menjelaskan bahwa pemilik/pemegang saham menyediakan sumber daya sedangkan manajemen diharuskan mengelola perusahaan. Sebagai bentuk pertanggung jawaban, pihak manajemen diharuskan melaporkan kondisi perusahaan melalui laporan keuangan. Laporan keuangan bertujuan untuk menyediakan informasi mengenai posisi keuangan, kinerja, serta perubahan posisi keuangan suatu perusahaan. Informasi yang terkandung dalam laporan keuangan harus menggambarkan kondisi perusahaan yang sebenarnya agar bermanfaat bagi pihak yang berkepentingan dalam pengambilan keputusan.

Teori keagenan juga menjelaskan bahwa prinsipal dan agen memiliki kepentingan berbeda (Jensen \& Meckling 1976). Teori ini menduga agen berusaha memaksimalkan keuntungan pribadi yang bisa diperoleh dengan bertindak secara oportunis. Untuk mengendalikan perilaku oportunis tersebut, prinsipal mendesain tata kelola perusahaan dengan menekankan fungsi monitoring terhadap kinerja agen.

Teori keagenan menjelaskan bahwa kualitas laporan keuangan adalah outcome dari konflik keagenan sekaligus fungsi monitoring pemegang saham terhadap manajemen. Oportunisme manajemen berusaha memanipulasi laporan keuangan untuk mengekstrak keuntungan pribadi sedangkan monitoring dari pemegang saham akan mengendalikannya. Oleh sebab itu, penelitian ini melibatkan variabel-variabel tata kelola untuk menjelaskan variasi kualitas laporan keuangan.

\section{Female CEO dan Kualitas Laporan Keuangan}

Secara umum, wanita dianggap lebih beretika dan memiliki team work yang lebih 
tinggi dibandingkan dengan pria. Keberadaan wanita dalam dewan direksi memberikan pengaruh yang baik bagi perusahaan. Shawver et al. (2006) menunjukkan bahwa akuntan wanita lebih kecil kemungkinannya untuk memilih tindakan seperti manajemen laba. Keragaman gender dengan lebih banyak eksekutif senior wanita dapat menghasilkan peningkatan kualitas laba yang dilaporkan (Krishnan \& Parsons 2008).

Penelitian Gavious et al. (2012), Perafah, H. (2018), Harakeh et al. (2019), dan Kouaib \& Almulhim (2019) membuktikan bahwa keragaman gender dewan direksi berpengaruh negatif signifikan terhadap manajemen laba. Hal ini dibuktikan dengan adanya rendahnya akrual diskresioner perusahaan, sehingga dapat meningkatkan kualitas pelaporan keuangan. Selain itu, pada perusahaan dengan peran wanita yang lebih tinggi, pemantauan oleh auditor dan kreditor tampak lebih lemah, namun kualitas laba lebih tinggi karena kehadiran wanita berfungi sebagai pemantauan internal (Gavious et al. 2012).

Penelitian serupa juga dilakukan oleh Peni \& Vahamaa (2010) dan Panzer \& Muller (2015). Hasil penelitian mereka membuktikan bahwa terdapat pengaruh antara keragaman dewan direksi dengan kualitas laporan keuangan karena eksekutif wanita menggunakan strategi manajemen laba yang lebih konservatif dan menghindari risiko, namun tidak dapat membuktikan adanya hubungan yang signifikan. Kyaw et al. (2015) menunjukkan bahwa tidak ada pengaruh antara keragaman gender dengan manajemen laba. Mereka mengungkapkan bahwa wanita hanya dapat membawa efek positif jika lingkungan kerja dapat memberdayakan mereka dengan baik.

Ketidakkonsistenan hasil penelitian dan argumen tentang hubungan antara keragaman gender dan kualitas laba, hipotesis yang diajukan adalah sebagai berikut:
H1 Female CEO berpengaruh terhadap kualitas laporan keuangan

\section{Preferensi Risiko Dalam Memoderasi Hubungan Female CEO Terhadap Kualitas Laporan Keuangan}

Risiko merupakan peluang peristiwa tidak diharapkan yang akan terjadi. Menurut Sudana (2015: 42) risiko investasi merupakan variabilitas hasil investasi yang sesungguhnya terhadap hasil investasi yang diharapkan. Dalam perusahaan, manajemen memiliki karakter yang berbeda dalam mengambil keputusan. Jenis karakter manajemen terbagi menjadi dua yaitu risk averse (menghindari risiko) atau risk taking (mengambil risiko). Terdapat anggapan bahwa wanita dan laki-laki memiliki perbedaan dalam mengambil risiko. Wanita pada umumnya lebih cenderung tidak suka mengambil risiko, sedangkan laki-laki lebih menyukai tantangan dan mengambil risiko yang lebih besar dibandingkan wanita. Perbedaan gender dalam preferensi risiko dapat terkait dengan emosi, overconfident, dan risk taking (Croson \& Gneezy 2009). Wanita cenderung mengalami emosi yang lebih kuat dibandingkan pria, sehingga dapat mempengaruhi keputusan yang diambil. Sedangkan pria cenderung lebih percaya diri dan lebih memilih untuk mengambil risiko.

Faccio et al. (2016) melakukan pengujian mengenai CEO gender dan corporate risk taking. Mereka menyimpulkan bahwa CEO wanita mampu mengurangi pengambilan risiko perusahaan yang dilakukan oleh pria. Penelitian yang dilakukan oleh Croson dan Gneezy (2009) mengungkapkan bahwa perilaku wanita cenderung untuk menolak risiko dibandingkan dengan pria. Keberagaman wanita dalam suatu perusahaan dengan segala karakter yang dimiliki oleh wanita dapat berpengaruh terhadap pengambilan keputusan perusahaan. Penelitian serupa juga dilakukan oleh Hoang et al. (2019) yang mengungkapkan bahwa perusahaan 
dengan CEO wanita memiliki indeks risiko yang lebih rendah daripada perusahaan dengan CEO pria.

Kendati banyak penelitian menunjukkan wanita cenderung mengambil risiko yang lebih rendah, Schubert et al. (1999) menunjukkan bahwa gender tidak memengaruhi kecenderungan mengambil risiko ketika konteks keputusan dipertimbangkan dalam model. Harrant dan Vaillant (2008) maupun Jianakoplos dan Bernasek (1999) menunjukkan bahwa hubungan antara gender dengan pengambilan risiko bergantung karakter individu.

Dalam menjelaskan kualitas laporan keuangan, gender eksekutif bisa jadi memiliki pengaruh. Namun demikian, gender saja tidak cukup bermanfaat ketika konteks keputusan berisiko dipertimbangkan dalam model. Oleh sebab itu, penelitian ini menduga preferensi risiko akan mempengaruhi hubungan antara gender eksekutif dengan kualitas laporan keuangan.

H2 Preferensi risiko memoderasi hubungan antara female CEO dengan kualitas laporan keuangan

\section{METODE PENELITIAN}

Pada penelitian ini, data yang digunakan adalah data sekunder. Data sekunder merupakan data penelitian yang diperoleh melalui sumber yang telah dikumpulkan oleh pihak lain. Data sekunder yang digunakan adalah laporan keuangan yang telah diaudit dan terdaftar di Bursa Efek Indonesia (BEI) untuk periode 2014 sampai 2018. Laporan keuangan tersebut diperoleh melalui database ORBIS dan website resmi BEl, yaitu www.idx.co.id.

Populasi yang digunakan dalam penelitian ini adalah perusahaan yang terdaftar di Bursa Efek Indonesia (BEI) untuk periode 2014 sampai 2018. Dari populasi tersebut ditentukan sampel dengan teknik purposive sampling dengan kriteria sebagai berikut:
1. Perusahaan non keuangan yang masih terdaftar sebagai emiten di BEI sampai 31 Desember 2018.

Perusahaan keuangan memiliki receivable yang terlalu besar dan karakteristik laporan keuangan unik yang akan mengganggu estimasi kualitas laporan keuangan berdasar akrual diskresionari. Penelitian ini menggunakan akrual diskresionari model Modified Jones untuk mengukur kualitas laporan keuangan yang menggunakan receivable sebagai pengurang revenue yang mengakibatkan minus beta akan semakin tinggi.

2. Perusahaan menerbitkan laporan tahunan selama periode 2014-2018 berturut-turut agar estimasi akrual diskresionari bisa dilakukan tanpa gangguan bias akibat data kosong.

3. Perusahaan melaporkan data dan informasi yang lengkap terkait dengan variabel yang diperlukan dalam penelitian ini.

Pada penelitian ini variabel independen adalah Female CEO. Variabel kontrol dalam penelitian ini adalah Size, Profitabilitas, Leverage, Pertumbuhan Perusahaan, Proporsi Dewan Direksi Independen, Proporsi Dewan Komisaris Independen, dan Big Four Auditor. Variabel dependen dalam penelitian ini adalah Kualitas Laporan Keuangan.

Pada penelitian ini, direktur utama wanita diukur dengan variabel dummy, yaitu observasi diberi nilai 1 jika direktur utamanya wanita sebagaimana yang dijelaskan dalam laporan tahunan. Variabel CEO diberi nilai 0 jika direktur utama bukan wanita (Gordini \& Rancati, 2016).

Kualitas pelaporan keuangan merupakan konstruk yang dapat dianalisis dalam dua pandangan, yaitu kualitas yang tercermin dalam laba perusahaan atau kualitas dalam bentuk imbalan (Fanani 2009). Pandangan yang sama dilakukan oleh Panzer dan Muller (2015) dengan mengklasifikasikan 
pengukurannya berdasarkan market-base dan accounting-base. Metode berbasis pasar mengukur kualitas laba dengan ukuran berbasis saham, sedangkan metode berbasis akuntansi mengukur kemampuan laba saat ini untuk memprediksi arus kas dan pendapatan di masa yang akan datang. Penelitian ini hanya berfokus pada metode berbasis akuntansi dengan proxy akrual diskresioner.

Akrual diskresioner digunakan untuk mengukur besaran manajemen laba yang dapat digunakan sebagai acuan kualitas pelaporan keuangan. Nilai akrual diskresioner digunakan tanpa tanda positif atau negatif yang menyertai (nilai absolut). Akrual diskresioner positif maupun negatif diasumsikan memiliki besaran yang sama apabila diukur dari angka nol. Nilai absolut akrual diskresioner merupakan ukuran terbalik (inverse measure) dari kualitas pelaporan keuangan. Semakin tinggi nilai absolut akrual, maka semakin rendah kualitas pelaporan keuangan. Nilai absolut akrual diskresioner diukur menggunakan Modified Jones Model (Dechow et al. 1996). Tahap penghitungan akrual diskresioner adalah:

1) Menghitung Total Accruals sebagai selisih antara laba bersih dan arus kas operasi.

$$
\mathrm{TA}_{\mathrm{it}}=\mathrm{Nl}_{\text {it }}-\mathrm{CFO}_{\text {it }}
$$

Selanjutnya, total akrual normal diestimasi pada level industri dengan persamaan (3.3). Periode estimasi total akrual sama dengan periode pengamatan penelitian ini yaitu 2014 sampai 2018.

$T A_{i t} / A_{i t-1}=\beta_{1}\left(1 / A_{i t-1}\right)+\beta_{2}\left(\Delta R E V_{i t} / A_{i t-}\right.$

$$
\text { 1) }+\beta_{3}\left(P P E_{i t} / A_{i t-1}\right)+\varepsilon
$$

2) Menghitung Nondiscretionary Accruals (NDA) menggunakan koefisien regresi total accrual pada persamaan (3.2). Data aktual pendapatan, piutang, PPE, dan aset perusahaan pada tahun pengamatan 2014 sampai 2018 dimasukkan dalam model
(3.3) untuk memperoleh NDA pada periode pengamatan.

$N D A_{i t}=\beta_{1}\left(1 / A_{i t-1}\right)+\beta_{2}\left(\Delta R E V_{i t} / A_{i t-1}-\right.$

$$
\left.\Delta R E C_{i t} / A_{i t-1}\right)+\beta_{3}\left(P P E_{i t} / A_{i t-1}\right)
$$

3) Menghitung Discretionary Accrual (ABSDA) sebagai selisih antara akrual total (persamaan 3.1) dengan NDA (persamaan 3.3)

$$
D A_{i t}=T A_{i t} / A_{i t-1}-N D A_{i t}
$$

Keterangan :

TAit = Total Accrual perusahaan $\mathrm{i}$ dalam periode tahun $\mathrm{t}$

NDAit $=$ Nondiscretionary Accruals perusahaan i dalam periode tahun $\mathrm{t}$

DAit = Discretionary Accruals perusahaan $\mathrm{i}$ dalam periode tahun $t$

Nlit = Laba bersih perusahaan $\mathrm{i}$ dalam periode tahun $t$

CFOit $=$ Arus kas dari aktivitas operasi perusahaan i dalam periode tahun $\mathrm{t}$

Ait-1 = Total aset perusahaan $\mathrm{i}$ dalam periode tahun $\mathrm{t}$

$\Delta$ Revit $=$ Perubahan revenue perusahaan $\mathrm{i}$ dalam periode tahun $t$

PPEit = Property, Plant, dan Equipment perusahaan i dalam periode tahun $t$

$\Delta$ Recit $=$ Perubahan receivable perusahaan $\mathrm{i}$ dalam periode tahun $t$

$\varepsilon \quad=$ error

Kecenderungan pengambilan risiko diukur dengan dua pengukuran. Pertama, standar deviasi ROA (STD_ROA) digunakan mengukur preferensi risiko eksekutif karena standar deviasi profitabilitas perusahaan menunjukkan penyimpangan di atas atau di bawah rata-rata (normal) dan hal itu mencerminkan risiko perusahaan. Semakin besar standar deviasi ROA maka semakin besar risiko yang ada dan menunjukkan eksekutif memiliki preferensi risk taking. Pengukuran standar deviasi ROA perusahaan $\mathrm{i}$ 
pada tahun t menggunakan ROA perusahaan $\mathrm{i}$ lima tahun berturut-turut sebelum tahun $\mathrm{t}$

Kedua, standar deviasi arus kas operasi (STD_CFO) digunakan untuk mengukur preferensi risiko. Ketidakpastian arus kas yang akan dihasilkan merupakan suatu hal yang diperkirakan oleh manajemen. Namun, terdapat kemungkinan realisasi arus kas akan menyimpang dari nilai yang telah diharapkan (normal/ rata-rata). Penyimpangan atau standar deviasi tersebut mencerminkan risiko perusahaan. Semakin tinggi standar deviasi arus kas maka semakin besar tingkat risiko perusahaan dan menunjukkan eksekutif memiliki preferensi risk taking. Pengukuran standar deviasi arus kas operasi perusahaan i pada tahun $t$ menggunakan arus kas operasi perusahaan i lima tahun berturut-turut sebelum tahun $\mathrm{t}$.

Penelitian ini menggunakan dua model analisis untuk menjelaskan hubungan antara CEO dengan akrual diskresioner absolut dan opini audit. Model (3.5) adalah regresi untuk menjelaskan hubungan antara CEO wanita dengan kualitas laporan keuangan yang diukur dengan akrual diskresioner absolut.

$A B S D A_{i t}=\alpha+\beta_{1} C E O_{i t}+\beta_{2} S I Z E_{i t}+\beta_{3} R O$

$$
\begin{aligned}
& A_{i t}++\beta_{4} L E V_{i t}+\beta_{5} \text { GROWT } \\
& H_{i t}+\beta_{6} \text { INDPDIR }{ }_{i t}+\beta_{7} \text { INDP }
\end{aligned}
$$

\section{$\mathrm{COM}_{i t}+\beta_{8} \mathrm{BIG}_{\mathrm{it}}+\varepsilon$}

Laporan auditor menjadi indikator keandalan laporan keuangan karena informasi hasil audit diasumsikan lebih lengkap, akurat, dan tidak bias (Arens et al, 2012). Laporan keuangan yang mendapat opini audit wajar tanpa pengecualian (unmodified audit opinion) akan mendapat kepercayaan yang lebih tinggi dari pemangku kepentingan daripada laporan keuangan yang mendapat opini audit selain wajar tanpa pengecualian (modified audit opinion). Oleh sebab itu penelitian ini juga menggunakan opini audit (AUOP) sebagai pengukuran alternatif kualitas pelaporan keuangan. Kualitas laporan keuangan perusahaan diberi nilai 1 jika perusahaan i mendapat opini audit wajar tanpa pengecualian pada tahun $t$ (unmodified audit opinion) dan 0 untuk perusahaan yang memiliki opini audit selain wajar tanpa pengecualian (modified audit opinion). Persamaan (3.6) adalah model regresi probit yang digunakan untuk menjelaskan hubungan antara CEO wanita dengan probabilitas mendapatkan opini wajar tanpa pengecualian.

$$
\begin{aligned}
& \operatorname{Pr}\left(A \cup O P_{i t}\right)=\alpha+\beta_{1} C_{E O} O_{i t}+\beta_{2} \text { SIZE }_{i t}+\beta_{3} \\
& R O A_{i t}++\beta_{4} L E V_{i t}+\beta_{5} G R O \\
& W T H_{i t}+\beta_{6} I N D P D\left|R_{i t}+\beta_{7}\right| \\
& \text { NDPCOMit }+\beta_{8} B I G 4_{i t}+\varepsilon
\end{aligned}
$$

\begin{tabular}{|c|c|c|c|c|c|}
\hline \multicolumn{6}{|c|}{ Panel A : Analisis Deskriptif } \\
\hline Variable & Obs & Mean & Std. Dev. & Min & Max \\
\hline$A B S D A$ & 1653 & .1890217 & .4665628 & .0000716 & 4.734686 \\
\hline$S T D \_R O A$ & 1653 & .0810555 & 3340228 & .0001434 & 5.641587 \\
\hline STD_CFO & 1653 & .0846681 & .2038349 & .0000314 & 2.001885 \\
\hline SIZE & 1653 & 21.68669 & 1. 641333 & 16.89403 & 25.5467 \\
\hline$R O A$ & 1653 & 0179465 & .2075065 & -5.159108 & 2.19203 \\
\hline LEV & 1653 & 1. 30852 & 2.704378 & -14.49148 & 24.77363 \\
\hline
\end{tabular}

\section{HASIL PENELITIAN}

Berikut ini adalah hasil statistik deskriptif dan independent sample t-test:

Tabel 1 Statistik Deskriptif 


\begin{tabular}{|c|c|c|c|c|c|}
\hline GROWTH & 1653 & .2283611 & 1.735021 & -.9988393 & 27.93605 \\
\hline INDPDIR & 1653 & 1822406 & 1484511 & 0 & .75 \\
\hline INDPCOM & 1653 & .404802 & 1155664 & 0 & 1 \\
\hline \multicolumn{6}{|l|}{ Panel B } \\
\hline & & \multicolumn{2}{|c|}{0} & \multicolumn{2}{|c|}{1} \\
\hline & & $\mathrm{N}$ & $(\%)$ & $\mathrm{N}$ & $(\%)$ \\
\hline CEO & 1653 & 1540 & 93,16 & 113 & 6,84 \\
\hline BIG4 & 1653 & 1077 & 65,15 & 576 & 34,85 \\
\hline
\end{tabular}

\begin{tabular}{|c|c|c|c|}
\hline Variabel & $\begin{array}{c}\text { Female CEO } \\
(n=113) \\
(\text { mean })\end{array}$ & $\begin{array}{c}\text { Male CEO }(n=1540) \\
\text { (mean) }\end{array}$ & $\begin{array}{r}\text { Mean test } \\
\text { (t-statistic) }\end{array}$ \\
\hline$A B S D A$ & 0.1779 & 0.1898 & 0.2612 \\
\hline SIZE & 21.015 & 21.737 & $4.5424^{* * *}$ \\
\hline$R O A$ & -0.0114 & 0.0201 & 1.5558 \\
\hline$L E V$ & 0.7589 & 1.3567 & $2.2411^{* *}$ \\
\hline GROWTH & 0.0965 & 0.2382 & 0.8378 \\
\hline INDPDIR & 0.1909 & 0.1816 & -0.6413 \\
\hline INDPCOM & 0.3897 & 0.4060 & 1.4390 \\
\hline BIG4 & 0.3009 & 0.3519 & 1.0993 \\
\hline
\end{tabular}

Berdasarkan tabel 1 dapat dideskripsikan hasil statistik yaitu nilai minimum dan maksimum untuk absolut akrual diskresioner (ABSDA) adalah 0 dan 4,735 dengan rata-rata (mean) yang dimiliki seluruh perusahaan sampel sebesar 0,189. Terdapat 540 perusahaan yang memiliki $A B S D A$ di atas rata-rata yang artinya cenderung melakukan earnings management.

Tabel 1 juga menunjukkan CEO memiliki nilai 1 sebanyak $6,83 \%$. Terdapat 113 dari 1653 perusahaan sampel memiliki direktur utama wanita artinya mayoritas perusahaan di Indonesia masih dipimpin oleh pria.

Volatilitas ROA (STD_ROA) dan volatilitas CFO (STD_CFO) merupakan variabel moderasi dalam penelitian ini. Variabel ini menunjukkan seberapa besar tingkat rentang fluktuasi yang mencerminkan tingkat risiko perusahaan. STD_ROA memiliki nilai minimum sebesar 0,004 dan nilai maksimum 0,298 serta memiliki mean sebesar 0,048 . Sebanyak 205 perusahaan memiliki STD_ROA diatas rata-rata atau preferensi risiko tinggi (risk taking). STD_CFO memiliki nilai minimum sebesar 0,008 dan nilai maksimum sebesar 0,185 serta memiliki mean sebesar 0,058 . Sebanyak 77 dari 1653 perusahaan memiliki preferensi risiko tinggi (risk taking).

Uji t-test dilakukan untuk mengetahui ada atau tidaknya perbedaan rata-rata antara perusahaan yang memiliki direktur utama wanita dan perusahaan yang memiliki direktur utama pria dalam mempengaruhi kualitas pelaporan keuangan.

Berdasarkan hasil uji beda independent sample t-test pada tabel 2, ABSDA tidak menunjukkan perbedaan yang signifikan. SIZE dan LEV memiliki perbedaan yang signifikan antara kedua grup tersebut. ROA, GROWTH, INDPDIR, INDPCOM dan BIG4 tidak memiliki perbedaan yang cukup signifikan antara 
perusahaan dengan direktur utama wanita dan perusahaan dengan direktur utama pria.

Tabel 3 merupakan ringkasan mengenai hasil regresi linear berganda dengan absolut akrual diskresioner (ABSDA) sebagai variabel dependen dan female CEO diukur dengan dummy dewan direksi wanita (CEO) sebagai variabel independen. Model regresi tersebut mempunyai variabel kontrol yaitu ukuran perusahaan (SIZE), profitabilitas (ROA), leverage (LEV), dan pertumbuhan perusahaan (GROWTH), jumlah dewan direksi independen (INDPDIR), jumlah dewan komisaris independen (INDPCOM), dan big four auditor (BIG4).
Berdasarkan hasil tabel 3 tersebut, besaran nilai R2 menunjukkan angka 0,023 artinya hanya sebesar 2,3\% variabel-variabel diatas dapat menjelaskan regresi tersebut sedangkan sisanya dijelaskan oleh variabelvariabel lain yang tidak digunakan dalam penelitian ini. Nilai koefisien CEO bernilai negatif namun tidak memiliki tingkat signifikan terhadap ABSDA. Variabel CEO hanya berpengaruh $2,3 \%$ artinya variabel independen sangat kecil dalam mempengaruhi variabel dependen. Nilai koefisien CEO tidak signifikan yang berarti CEO wanita tidak memiliki pengaruh terhadap kualitas laporan keuangan perusahaan. Dengan demikian, $\mathrm{H} 1$ penelitian ini tidak terbukti.

Tabel 3 Analisis Regresi Linier Berganda

\begin{tabular}{lc} 
VARIABLES & ABSDA \\
\hline \multirow{2}{*}{ CEO } & -0.023 \\
& $(0.044)$ \\
SIZE & $-0.042^{* * *}$ \\
& $(0.008)$ \\
ROA & -0.070 \\
& $(0.052)$ \\
LEV & 0.001 \\
& $(0.004)$ \\
GROWTH & $0.014^{* *}$ \\
& $(0.006)$ \\
INDPDIR & 0.033 \\
& $(0.075)$ \\
INDPCOM & -0.073 \\
& $(0.094)$ \\
BIG4 & 0.011 \\
& $(0.025)$ \\
Constant & $1.181^{* * *}$ \\
& $(0.184)$ \\
Observations & 1,653 \\
R & 0,023 \\
Number of sic2r & 39 \\
\hline Stand &
\end{tabular}

Standard errors in parentheses

${ }^{* * *} p<0.01,{ }^{* *} p<0.05,{ }^{*} p<0.1$ 
Selanjutnya, penelitian ini berusaha melihat efek preferensi risiko terhadap hubungan antara CEO wanita dan kualitas laporan keuangan. Tabel 4 menunjukkan hasil regresi linier variabel CEO terhadap $A B S D A$ dengan preferensi risiko sebagai variabel moderasi. Kolom (1) menyajikan efek moderasi preferensi risiko yang diukur dengan STD_ROA sedangkan kolom (2) menyajikan efek moderasi preferensi risiko yang diukur dengan STD_CFO. RISKROA dan RISKCFO merupakan preferensi risiko CEO wanita yang diukur dengan mengalikan standar deviasi ROA
(STD_ROA) dan standar deviasi CFO (STD_CFO) dengan CEO. Berdasarkan tabel tersebut, R2 bernilai 3,3\% dan $9,7 \%$. Variabel $S T D \_R O A$ dan STD_CFO memiliki nilai koefisien positif yaitu sebesar 0,08 dan 0,51. Variabel-variabel tersebut memiliki nilai $p$-value sebesar 0,015 dan 0,0 artinya variabel tersebut berpengaruh signifikan pada tingkat $5 \%$ dan $1 \%$ terhadap ABSDA. Perusahaan dengan preferensi risiko tinggi cenderung untuk melakukan earnings management sehingga dapat menurunkan kualitas pelaporan keuangan.

Tabel 4 Analisis Regresi Linier dengan Moderasi

\begin{tabular}{|c|c|c|}
\hline VARIABLES & $\begin{array}{c}(1) \\
\text { ABSDA }\end{array}$ & $\begin{array}{c}(2) \\
\text { ABSDA }\end{array}$ \\
\hline CEO & $\begin{array}{l}-0.050 \\
(0.046)\end{array}$ & $\begin{array}{l}-0.026 \\
(0.065)\end{array}$ \\
\hline$S T D \_R O A$ & $\begin{array}{l}0.085^{\star *} \\
(0.035)\end{array}$ & \\
\hline RISKROA & $\begin{array}{l}0.261^{* *} \\
(0.123)\end{array}$ & \\
\hline STD_CFO & & $\begin{array}{c}0.514^{* * *} \\
(0.054)\end{array}$ \\
\hline RISKCFO & & $\begin{array}{c}0.274 \\
(0.976)\end{array}$ \\
\hline SIZE & $\begin{array}{c}-0.039^{* * *} \\
(0.008)\end{array}$ & $\begin{array}{c}-0.036^{* * *} \\
(0.008)\end{array}$ \\
\hline ROA & $\begin{array}{c}0.020 \\
(0.058)\end{array}$ & $\begin{array}{l}-0.075 \\
(0.052)\end{array}$ \\
\hline LEV & $\begin{array}{c}0.002 \\
(0.004)\end{array}$ & $\begin{array}{c}0.003 \\
(0.004)\end{array}$ \\
\hline GROWTH & $\begin{array}{l}0.014^{* *} \\
(0.006)\end{array}$ & $\begin{array}{c}0.009 \\
(0.006)\end{array}$ \\
\hline INDPDIR & $\begin{array}{c}0.044 \\
(0.075)\end{array}$ & $\begin{array}{c}0.012 \\
(0.075)\end{array}$ \\
\hline INDPCOM & $\begin{array}{l}-0.081 \\
(0.094)\end{array}$ & $\begin{array}{l}-0.137 \\
(0.094)\end{array}$ \\
\hline BIG4 & $\begin{array}{c}0.009 \\
(0.025)\end{array}$ & $\begin{array}{c}0.008 \\
(0.025)\end{array}$ \\
\hline Constant & $\begin{array}{l}1.112^{* * *} \\
(0.187)\end{array}$ & $\begin{array}{l}1.009^{* * *} \\
(0.175)\end{array}$ \\
\hline Observations & 1,653 & 1,653 \\
\hline $\mathrm{R}^{2}$ & 0.033 & 0.097 \\
\hline Number of sic2r & 39 & 39 \\
\hline
\end{tabular}


Variabel RISKROA memiliki nilai koefisien positif yaitu sebesar 0,26 dan memiliki nilai $p$-value sebesar 0,33 artinya variabel tersebut berpengaruh signifikan pada tingkat $5 \%$ terhadap ABSDA. Hasil tersebut menunjukkan bahwa CEO wanita dengan preferensi risiko tinggi (risk taking) mempunyai kecenderungan untuk melaporkan akrual diskresionari absolut yang lebih tinggi. Hasil tersebut berbeda dengan hasil yang ditunjukkan oleh variabel RISKCFO. RISKCFO memiliki nilai koefisien positif namun tidak menunjukkan adanya pengaruh yang signifikan. Hal ini menunjukkan bahwa preferensi risiko dengan pengukuran STD_CFO tidak memiliki pengaruh terhadap hubungan $C E O$ dengan ABSDA.

Berdasarkan hasil model regresi di atas, diperoleh informasi bahwa variabel STD_ROA dan variabel RISKROA signifikan, maka variabel preferensi risiko sebagai variabel Moderasi Semu (Quasi Moderator). Variabel quasi moderator merupakan variabel yang dapat memoderasi hubungan variabel independen (CEO) dengan variabel dependen (ABSDA) dan juga sekaligus sebagai variabel independen terhadap $A B S D A$.

Variabel RISKCFO dapat

diklasifikasikan sebagai variabel Prediktor
Moderasi (Predictor Moderator). Hal ini dikarenakan variabel STD_CFO menunjukkan pengaruh signifikan namun variabel RISKROA tidak menunjukkan pengaruh signifikan. Variabel Predictor Moderator adalah variabel moderasi yang hanya berperan sebagai prediktor atau hanya sebagai variabel independen dan tidak berperan sebagai variabel moderasi dalam model regresi tersebut.

Audit opinion (AUOP) merupakan variabel untuk mengukur kualitas pelaporan keuangan selain ABSDA. AUOP merupakan variabel dummy, nilai 1 diberikan kepada perusahaan yang mendapatkan opini audit wajar tanpa pengecualian (unmodified audit opinion) dan nilai 0 untuk perusahaan mendapatkan selain opini audit wajar tanpa pengecualian (modified audit opinion). Persentase AUOP yang memiliki angka 1 sebesar $45,95 \%$ sedangkan sisanya $54,05 \%$ memiliki angka 0. Terdapat 760 perusahaan yang mendapatkan opini audit WTP dengan 61 perusahaan dipimpin Direktur Utama wanita, sedangkan perusahaan yang dipimpin Direktur Utama pria sebanyak 699 perusahaan.

Tabel 5 Hasil Regresi Probit

\begin{tabular}{lcc}
\hline VARIABLES & AUOP & $\begin{array}{c}\text { Marginal } \\
\text { Effect }\end{array}$ \\
\hline CEO & $0.271^{* *}$ & 0.099 \\
SIZE & $(0.128)$ & \\
& -0.009 & -0.003 \\
ROA & $(0.022)$ & \\
& $0.401^{* *}$ & 0.146 \\
LEV & $(0.148)$ & \\
& -0.017 & -0.006 \\
GROWTH & $(0.012)$ & \\
& $-0.067^{*}$ & -0.025 \\
INDPDIR & $(0.037)$ & \\
& $-0.548^{* *}$ & -0.199 \\
INDPCOM & $(0.223)$ & \\
& -0.227 & -0.083 \\
& $(0.277)$ &
\end{tabular}




\begin{tabular}{lcc} 
BIG4 & $0.775^{\star * *}$ & 0.282 \\
& $(0.074)$ & \\
Constant & 0.028 & \\
& $(0.486)$ & \\
\hline Observations & 1,653 \\
Pseudo $R^{2}$ & 0.077 & \\
\hline Standard errors in parentheses & \\
${ }^{* * *} p<0.01,{ }^{* *} p<0.05,{ }^{*} p<0.1$ &
\end{tabular}

Pada tabel 5 menunjukkan ringkasan mengenai hasil probit regression analysis persamaan (3.6) dengan opini audit (AUOP) sebagai variabel dependen dan female CEO diukur dengan dummy dewan direksi wanita (CEO) sebagai variabel independen. Model regresi tersebut mempunyai variabel kontrol yaitu ukuran perusahaan (SIZE), profitabilitas $(R O A)$, leverage (LEV), dan pertumbuhan perusahaan (GROWTH), jumlah dewan direksi independen (INDPDIR), jumlah dewan komisaris independen (INDPCOM), dan big four auditor (BIG4).

Tabel 6 Hasil Regresi Probit dengan Variabel Moderasi

\begin{tabular}{|c|c|c|c|c|}
\hline \multirow{3}{*}{ VARIABLES } & \multicolumn{2}{|c|}{$(1)$} & \multirow{2}{*}{\multicolumn{2}{|c|}{$\frac{(2)}{A U \cap P}$}} \\
\hline & & & & \\
\hline & Probit Reg. & $\begin{array}{c}\text { Marginal } \\
\text { Effect }\end{array}$ & Probit Reg. & $\begin{array}{c}\text { Marginal } \\
\text { Effect }\end{array}$ \\
\hline CEO & $\begin{array}{c}0.211 \\
(0.134)\end{array}$ & 0.077 & $\begin{array}{c}0.303 \\
(0.194)\end{array}$ & 0.110 \\
\hline STD_ROA & $\begin{array}{c}-0.398^{* * *} \\
(0.151)\end{array}$ & -0.144 & & \\
\hline RISKROA & $\begin{array}{c}0.611 \\
(0.372)\end{array}$ & 0.222 & & \\
\hline STD_CFO & & & $\begin{array}{l}-0.188 \\
(0.165)\end{array}$ & -0.068 \\
\hline RISKCFO & & & $\begin{array}{l}-0.829 \\
(2.985)\end{array}$ & -0.302 \\
\hline SIZE & $\begin{array}{l}-0.018 \\
(0.022)\end{array}$ & -0.007 & $\begin{array}{l}-0.011 \\
(0.022)\end{array}$ & -0.004 \\
\hline ROA & $\begin{array}{l}0.415^{\star *} \\
(0.180)\end{array}$ & 0.151 & $\begin{array}{c}0.407^{\star * *} \\
(0.148)\end{array}$ & 0.148 \\
\hline LEV & $\begin{array}{l}-0.019 \\
(0.013)\end{array}$ & -0.007 & $\begin{array}{l}-0.017 \\
(0.012)\end{array}$ & -0.006 \\
\hline GROWTH & $\begin{array}{l}-0.068^{*} \\
(0.038)\end{array}$ & -0.025 & $\begin{array}{l}-0.064^{*} \\
(0.037)\end{array}$ & -0.023 \\
\hline INDPDIR & $\begin{array}{c}-0.575^{* *} \\
(0.223)\end{array}$ & -0.209 & $\begin{array}{l}-0.544^{* *} \\
(0.223)\end{array}$ & -0.198 \\
\hline INDPCOM & $\begin{array}{l}-0.207 \\
(0.277)\end{array}$ & -0.075 & $\begin{array}{l}-0.215 \\
(0.277)\end{array}$ & -0.078 \\
\hline BIG4 & $\begin{array}{c}0.777^{* * *} \\
(0.074)\end{array}$ & 0.282 & $\begin{array}{c}0.778^{* * *} \\
(0.074)\end{array}$ & 0.283 \\
\hline
\end{tabular}




\begin{tabular}{lcc} 
Constant & 0.252 & 0.082 \\
& $(0.493)$ & $(0.490)$ \\
& & \\
Observations & 1,653 & 1,653 \\
Pseudo R & 0.081 & 0.077 \\
\hline
\end{tabular}

Berdasarkan tabel 5 tersebut, nilai Pseudo $\mathrm{R}^{2}$ sebesar 0,077 artinya $7,7 \%$ besar kontribusi variabel-variabel yang digunakan untuk menjelaskan model tersebut, sedangkan sisanya dijelaskan oleh variabel-variabel lain yang tidak digunakan. Nilai koefisien CEO memiliki nilai 0,27 dan $p$-value sebesar 0,033 yang menunjukkan terdapat pengaruh positif signifikan pada tingkat 10\%. Perusahaan dengan CEO wanita memiliki probabilitas lebih tinggi $9,9 \%$ untuk mendapatkan opini wajar tanpa pengecualian (WTP) dibandingkan dengan perusahaan dengan CEO laki-laki, ceteris paribus.

Selanjutnya, penelitian ini juga melihat efek preferensi risiko terhadap hubungan CEO wanita dengan kualitas laporan keuangan yang diukur melalui pengukuran alternatif yaitu AUOP. Hasilnya disajikan dalam tabel 6.

Tabel 6 menunjukkan hasil regresi probit variabel CEO terhadap AUOP dengan preferensi risiko sebagai variabel moderasi. Kolom (1) menyajikan efek moderasi preferensi risiko yang diukur dengan STD_ROA sedangkan kolom (2) menyajikan efek moderasi preferensi risiko yang diukur dengan STD_CFO. Berdasarkan tabel tersebut, Pseudo $\mathrm{R}^{2}$ pada kedua kolom tersebut bernilai 0.081 dan 0.077 artinya kontribusi variabel yang digunakan sebesar $8,1 \%$ dan $7,7 \%$ sedangkan sisanya dijelaskan oleh variabel lain yang tidak digunakan dalam penelitian ini.

Variabel STD_ROA dan STD_CFO memiliki nilai koefisien negatif yaitu sebesar 0,398 dan $-0,188$. Namun hanya variabel $S T D \_R O A$ yang memiliki nilai $p$-value sebesar 0,008 artinya variabel tersebut berpengaruh signifikan pada tingkat $1 \%$ terhadap AUOP. Perusahaan dengan preferensi risiko tinggi cenderung mendapatkan opini audit wajar tanpa pengecualian.

Variabel RISKROA memiliki nilai koefisien positif dengan nilai $p$-value sebesar 0,10 artinya variabel tersebut berpengaruh signifikan pada tingkat 10\% terhadap AUOP. Hasil tersebut menunjukkan bahwa CEO wanita dengan preferensi risiko tinggi cenderung mendapatkan opini audit WTP dengan probabilitas $7,7 \%$, ceteris paribus. Hasil interpretasi preferensi risiko CEO wanita terhadap pengukuran alternatif $A \cup O P$ tidak konsisten dengan hasil regresi pada variabel $A B S D A$. Variabel $R I S K C F O$ tidak menunjukkan adanya pengaruh yang signifikan.

Berdasarkan hasil penelitian ini, diketahui bahwa direktur utama wanita tidak menunjukkan adanya pengaruh yang signifkan terhadap kualitas laporan keuangan. Hasil uji ttest juga menunjukkan bahwa antara direktur wanita dengan direktur utama pria tidak memiliki perbedaan dalam menentukan akrual diskresioner.

Penelitian ini konsisten dengan penelitian yang dilakukan oleh Peni \& Vahama (2010) dan Panzer \& Muller (2015) yang menyatakan bahwa tidak ada pengaruh yang signifikan antara direktur utama wanita dengan kualitas pelaporan keuangan. Hal yang mungkin dapat menyebabkan tidak adanya pengaruh tersebut adalah jumlah perusahaan di Indonesia dengan direktur utama wanita masih terlalu sedikit dibandingkan dengan jumlah perusahaan dengan direktur utama pria. Perusahaan dengan direktur utama wanita hanya 6,83\% dari keseluruhan sampel perusahaan, sehingga pengaruhnya terhadap kualitas pelaporan keuangan tidak tampak. Hasil penelitian ini sesuai dengan temuan Kyaw et al (2015) pada perusahaan di Eropa yang menunjukkan bahwa 
tidak ada pengaruh antara keragaman gender dengan earnings management. Mereka mengungkapkan bahwa wanita akan memiliki pengaruh yang baik bagi perusahaan jika perusahaan tersebut dapat memberdayakan wanita dengan baik pula.

Sedikitnya peran wanita dalam kepemimpinan di Indonesia diakibatkan oleh beragamnya tradisi dan stigma masyarakat Indonesia. Stigma-stigma kuno yang masih melekat di benak masyarakat membuat wanita susah untuk berkembang dan meraih mimpinya. Stigma tersebut adalah responsibility in the home. Selain itu, masalah yang menghambat wanita untuk menjadi pemimpin adalah perasaan rendah diri. Wanita Indonesia cenderung memiliki sifat yang kurang percaya dengan kemampuannya sendiri. Selain itu, wanita juga dianggap kurang berkontribusi dalam perusahaan .

Dalam penelitian ini ditemukan bahwa perusahaan dengan CEO pria mempunyai proporsi direksi wanita dengan rata-rata 0,1 . Sedangkan jika perusahaan dengan CEO wanita cenderung memiliki direksi wanita empat kali lipat lebih banyak dibandingkan dengan direksi yang dimiliki oleh perusahaan CEO pria. Namun, rata-rata direksi wanita tersebut hanya 0,4 sedangkan sisanya adalah pria. Hal ini membuktikan bahwa majority masih dimiliki oleh pria sehingga efek hubungan dalam penelitian ini tidak terlihat.

Hasil penelitian ini bertentangan dengan penelitian yang dilakukan oleh Gavious et al (2012), Kouaib \& Almulhim (2019) dan Harakeh et al (2019). Mereka menunjukkan bahwa CEO wanita berpengaruh signifikan terhadap akrual diskresioner. Perbedaan tersebut disebabkan oleh jumlah eksekutif wanita di berbagai negara maju lebih banyak dibandingkan dengan Indonesia. Harakeh et al (2019) mengungkapkan bahwa perusahaanperusahaan di Inggris diharuskan meningkatkan keberadaan wanita dalam dewan direksi sesuai dengan amanat yang diatur dalam Davies Report 2011. Sehingga, hasil penelitian ini dapat berbeda dengan penelitian sebelumnya karena eksekutif wanita masih sangat sedikit, dimana hampir seluruh jabatan diduduki oleh laki-laki.

Dalam model penelitian dengan menggunakan opini audit sebagai pengukur alternatif kualitas pelaporan keuangan, direktur utama wanita memiliki pengaruh positif dan signifikan pada tingkat $5 \%$. Hal ini menunjukkan adanya peluang wanita yang lebih tinggi untuk mendapatkan opini audit wajar tanpa pengecualian (WTP), sehingga dapat meningkatkan kualitas pelaporan keuangan. Laporan keuangan yang mendapat opini audit WTP dapat meningkatkan kepercayaan investor atau pemangku kepentingan lainnya.

Hasil analisis dengan preferensi risiko menunjukkan pengaruh yang signifikan. Hal ini menunjukkan perusahaan dengan preferensi risiko tinggi punya kecenderungan untuk melakukan earnings management, sehingga dapat menurunkan kualitas pelaporan keuangan.

Penelitian yang dilakukan oleh Faccio et al (2016) mengatakan bahwa CEO wanita memiliki sifat risk averse dan mampu mengurangi pengambilan risiko yang dilakukan oleh pria. Seorang CEO yang memiliki sifat risk averse biasanya memilih segala tindakan dengan risiko yang lebih rendah dan mengutamakan keamanan walaupun mendapat laba yang lebih kecil dibandingkan dengan keuntungan besar namun berisiko. Namun, dalam penelitian ini wanita yang memiliki sifat (risk taking) cenderung untuk melakukan earnings management. Hal ini menunjukkan pernyataan bahwa wanita lebih menghindari risiko hanya stereotype. Tidak ada perbedaan antara pria dan wanita dalam memilih risiko yang akan diambil dalam suatu keputusan. 


\section{PENUTUP}

Penelitian ini menyimpulkan bahwa female CEO mampu mengurangi akrual diskresioner perusahaan namun tidak terbukti signifikan terhadap kualitas laporan keuangan. Jumlah wanita yang menduduki posisi CEO perusahaan sangat sedikit sehingga menyebabkan hubungan tersebut tidak signifikan. Berdasarkan analisis tambahan, female CEO berpengaruh positif terhadap opini audit wajar tanpa pengecualitan sehingga dapat meningkatkan kualitas laporan keuangan.

Hasil analisis dengan variabel moderasi menunjukkan preferensi risiko dapat memoderasi hubungan female CEO dan kualitas laporan keuangan. Penelitian ini menduga bahwa CEO wanita juga memiliki keberanian sama halnya dengan pria dalam mengambil risiko untuk melaporkan kinerja perusahaan yang memuaskan sehingga akan mengurangi kualitas laporan keuangan.

Dalam menginterpretasi hasil temuan penelitian ini, pembaca harus berhati-hati karena terdapat keterbatasan penelitian. Penelitian ini mengklasifikasikan kualitas laporan keuangan hanya berdasarkan beberapa pengukuran, yaitu akrual diskresioner perusahaan dan opini audit, dimana hal tersebut bisa saja tidak mencerminkan sepenuhnya penyimpangan yang dilakukan manajemen dalam menyusun laporan keuangan.

Menimbang adanya keterbatas penelitian ini, peneliti selanjutnya dapat meneliti dengan menambahkan pengukuran lain yang dapat membantu untuk mencerminkan penyimpangan yang dilakukan oleh manajemen dalam menyajikan laporan keuangan.

\section{REFERENCES:}

Adams, Renee B. \& Ferreira, Daniel. 2009. Women in the boardroom and their impact on governance and performance. Journal of Financial Economics 94, 291-309.

Al-Shaer, Habiba., \& Zaman, Mahbub. 2016. Board keragaman gender and sustainability reporting quality. Journal of Contemporary Accounting \& Economics 12, 210-222

Arens A., Randal, J. E., Mark S, Beasley. 2012. Auditing and Assurance Service: An Integrated Approach 14th edition. New Jersey: Prentice-Hall.

Carter, David A., Simkins, Betty J., \& Simpson, W. Gary. 2003. Corporate Governance, Board Diversity, and Firm Value. The Financial Review 38, 33-53

Croson, R., \& Gneezy, U. 2009. Gender Differences in Preferences. Journal of Economic Literature, 47:2, 448474

Dechow, Patricia, M., Sloan, R.G., and Sweeney, A.P. 1996. Causes and Consequences of Earnings Manipulaton: An Analysis of Firms Subject to Enforcement Actions by the SEC. Contemporary Accounting Research, 13, 1-36.

Faccio, M., Marchica, M. T., \& Mura, R. 2016. CEO gender, corporate risk-taking, and the efficiency of capital allocation. Journal of Corporate Finance 39, 193-209

Fanani, Zaenal, Ningsih, Sri \& Hamidah. 2009. Faktor-Faktor Penentu Kualitas Pelaporan Keuangan Dan Kepercayaan Investor. Simposium Nasional Akuntansi XII, 1-32.

Fanani, Zaenal. 2009. Kualitas Pelaporan Keuangan: Berbagai Faktor Penentu Dan Konsekuensi Ekonomis. Jurnal Akuntansi dan Keuangan Indonesia, Vol. 6, No. 1, hal 20 - 45.

Gavious, Ilanit., Segev, Einav., \& Yosef, Rami. 2012. Female directors and earnings management in hightechnology firms. Pacific Accounting Review Vol. 24 No. 1.

Gordini, N., \& Rancati, Elisa. 2016. Keragaman gender In The Italian Boardroom And Firm Financial Performance. Management Research Review Vol. 40 No. 1, pp. 75-94. 
Grant Thornton International. 2019. Women in Business: Building A Blueprint for Action. Diakses pada 29 Februari 2020 dari https://www.grantthornton.global/en/insights/women-in-business-2019/women-inbusiness-report-2019/

Harakeh, Mostafa., El-Gammal, Walid., \& Matar, Ghida. 2019. Female directors, earnings management, and CEO incentive compensation: UK evidence. Research in International Business and Finance 50, 153170

Hoang, Tuyen T., Nguyen, Cuong V., \& Tran, Hoa Thi V. 2019. Are female CEOs more risk averse than male counterparts? Evidence from Vietnam. Economic Analysis and Policy 63, 57-74.

Ting, Irene Wei K., Azizan, Noor A. B., \& Kweh, Qian Long . 2015. Upper Echelon Theory Revisited: The relationship between CEO Personal Characteristics and Financial Leverage Decision. Procedia - Social and Behavioral Sciences 195, $686-694$.

Jensen, Michael C., \& Meckling, William H. 1976. Theory Of The Firm: Managerial Behavior, Agency Costs and Ownership Structure. Journal of Financial Economics 3, 305-360.

Kaplan, S., Pany K., Samuels, J. \& Zhang, J. 2009. An Examination of the Association Between Gender and Reporting Intentions for Fraudulent Financial Reporting. Journal of Business Ethics 87:15-30.

Kılıç, Merve \& Kuzey, Cemil. 2016. The effect of board keragaman gender on firm performance: evidence from Turkey. Gender in Management: An International Journal Vol. 31 No. 7, 434-455.

Kouaib, A. \& Almulhim, A. 2019. Earnings manipulations and board's diversity: The moderating role of audit. Journal of High Technology Management Research, 30, 100356.

Krishnan, G. V., \& Parsons, L. M. 2008. Getting to the Bottom Line: An Exploration of Gender and Earnings Quality. Journal of Business Ethics 78:65-76

Kyaw, K., Olugbode, M., \& Petracci, B. 2015. Does gender diverse board mean less earnings management?. Finance Research Letters 14. 135-141

Manner M. H. 2010. The Impact of CEO Characteristics on Corporate Social Performance. Journal of Business Ethics 93: 53-72.

Panzer, L. \& Muller, Stefan. 2015. Earnings quality and keragaman gender on German supervisory boards: an empirical analysis. Problems and Perspectives in Management, Volume 13, Issue 4.

Peni, Emilia. \& Vahamaa, Sami. 2010. Female executives and earnings management. Managerial Finance Vol. 36 №. 7.

Perafán, H. 2018. Board keragaman gender and earnings quality. Evidence from the Latin American integrated market (MILA). Contaduría Universidad de Antioquia, 72, 151-163

Rana Wehbe. 2019. Asia's Power Businesswomen 2019: Meet 25 Outstanding Leaders On The Rise In Asia. Diakses pada 29 Februari 2020, dari https://www.forbes.com/sites/ranawehbe/2019/09/23/asias-powerbusinesswomen-2019-meet-25-outstanding-leaders-on-the-rise-in-asial

Rose, Caspar. 2007. Does female board representation influence firm performance? The Danish evidence. Journal compilation. Volume 15, No. 2

Sadia, Ni Putu Mira D. \& Sukartha, I Made. 2014. Pengaruh Pergantian Ceo Pada Praktik Manajemen Laba Perusahaan Publik Yang Terdaftar Di Bursa Efek Indonesia. E-Jurnal Akuntansi Universitas Udayana 8.1, 200-210.

Shawver, Tara J., Bancroft, P. and Sennetti, John T., 2006, Can the 'Clan Effect' Reduce the Gender Sensitivity to Fraud? The Case of the IPO Environment, Journal of Forensic Accounting, 7, 185-208.

Sila, Vathunyoo., Gonzalez, Angelica., \& Hagendorff, Jens. 2016. Women on board: Does boardroom keragaman gender affect firm risk?. Journal of Corporate Finance 36, 26-53

Smith, Nina, Smith, Valdemar Smith, \& Verner, Mette. 2005. Do Women in Top Management Affect Firm Performance? A Panel Study of 2500 Danish Firms. IZA Discussion Paper No. 1708.

Sudana, I Made. 2015. Manajemen Keuangan Perusahaan. Edisi Kedua. Jakarta: Erlangga

Taleb, Hanan M. 2010. Gender and leadership styles in single-sex academic institutions. International Journal of Educational Management Vol. 24 No. 4, pp. 287-302. 